\title{
Pastoraal bidden als samenspraak
}

\author{
R.J. de Vries
}

\begin{abstract}
Presenting the results of a qualitative research on the practice of prayer in pastoral care, this article discusses the questions which most interest ministers in the Protestant Church in the Netherlands. Dialogue - between the pastor and the other, and between the conversation partners and God - is a key issue. The article presents a three-dimensional model of this dialogue and elaborates a theology of pastoral prayer as spiritual fellowship. It then argues that in pastoral care, ministers, with their conversation partners, should pay more attention to the theological quality and the practical significance of dialogue on praying together.
\end{abstract}

\section{Pastoraal bidden herleeft}

Pastoraal bidden is in beweging. Het recente Handboek voor ouderling \& bezoekmedewerker stelt bijvoorbeeld: 'Er is een tijd geweest dat dit [bidden] nauwelijks meer gebeurde. De laatste jaren groeit het besef hoe waardevol het gebed kan zijn'. ${ }^{1}$ Ik zie dat terug bij predikanten die deelnamen aan cursussen over pastoraal bidden. Een predikant (bijna 60 jaar) schrijft in 2015: 'Er is ook bij mij veel veranderd en ook ik ben kind van mijn tijd. 25 jaar terug bad ik niet of nauwelijks in het pastoraat, inmiddels ben ik meer en meer overtuigd geraakt van de waarde en doe ik het vaak'. In grote delen van de kerken in Nederland is deze waardering voor het pastorale gebed er steeds geweest. Toch is ook daar bij sommigen iets in beweging. Zo merkt een predikant uit de orthodox-gereformeerde traditie in de cursus van 2017 op: 'Het gebed als afsluitend ritueel is slechts een "vroom" sausje waarmee de pastorant dichtgesmeerd en overgoten wordt. Dat is de huidige situatie die ik bij mezelf aantref. Deze predikant wil die praktijk veranderen en hij was in de cursussen niet de enige.

1 E. Hoebe-de Waard en R. de Wit, Handboek voor de ouderling en bezoekmedewerker, Utrecht 2019, hoofdstuk 6.4. Vgl. R. Ganzevoort en J. Visser, Zorg voor het verhaal, Zoetermeer 2007, 240-254. N. Dijkstra-Algra, Pastoraat voor iedereen, Zoetermeer 20166, 69 wees in 2000 al op deze trendbreuk: 'De laatste jaren groeit het verlangen opnieuw'. Vgl. E.S. Klein-Kranenburg, 'Samen in de Naam van Jezus - Bijbel en gebed in het pastoraat', in: H.C. van der Meulen, Liefdevol oog en open oor, Zoetermeer 20104, 329-333. 
Deze hernieuwde belangstelling voor pastoraal bidden past in de context van de religieuze ontwikkelingen in onze samenleving. In onze seculiere tijd spreekt bidden niet meer vanzelf. Volgens het Sociaal en Cultureel Planbureau bidt driekwart van de niet-kerkgangers nooit. Ook bij kerkleden is de vanzelfsprekendheid afgenomen. Twee generaties terug praktiseerde nog $60 \%$ van de hervormde gezinnen de dagelijkse gewoonte van gezamenlijk gebed en bijbellezing, dat is nu gekelderd naar $12 \%$. Anderzijds bidt van de kerkleden twee derde met minstens wekelijkse frequentie en van de regelmatige kerkgangers doet vrijwel iedereen dit (95\%). ${ }^{2}$ Echter, de toegenomen diversiteit in de religieus-culturele context leidt tot een grote variatie aan opvattingen over (inhoud en) manieren van bidden (vorm). Immink wijst naast de rol van de seculiere context bijvoorbeeld ook op de invloed van overtuigde gebedspraktijken van migrantenchristenen, jongeren bij Youth for Christ of in Taizé en van evangelische christenen. ${ }^{3}$ Mensen maken daarin hun eigen keuzes. Processen van individualisering en multiculturalisering dragen eraan bij dat gelovigen minder gezag toekennen aan de kerk en aan de overgeleverde vormen en gebruiken. ${ }^{4}$ Ook in kerkelijke stromingen waar de traditie nog wel gezag heeft, komen via de media of eigen ervaringen op vakantie (bv. Taizé) of evenementen (bv. pinksterconferentie Opwekking) andere manieren van bidden binnen.

Het verlies aan vanzelfsprekendheid en de toegenomen verscheidenheid in vorm en inhoud van het gebed roepen vragen op en brengen voor gelovigen soms ook aanvechtingen met zich mee. ${ }^{5}$ Predikanten moeten zich in hun zielzorg tot deze vragen verhouden, maar delen zelf ook in de verlegenheid. ${ }^{6}$ Voor zover mij bekend is nauwelijks onderzoek gedaan naar de vraag hoe predikanten deze ontwikkelingen zelf ervaren. Deze lacune vormt de aanleiding voor het hier gepresenteerde onderzoek naar bidden in het pastoraat

2 J. de Hart en P. van Houwelingen, Christenen in Nederland, SCP 2018, 68-71.

3 F.G. Immink, 'Tot God bidden in een seculiere wereld', Theologia Reformata 56/1 (2013), 9-13.

4 Ganzevoort, Zorg, 41-67 en 240-242.

5 P. Veerman, 'Gebed en aanvechting. Ervaring van de Reformatie voor een seculiere tijd', Theologia Reformata 62 (2019), 119-134. Veerman noemt drie kenmerken van de seculiere context: het veranderde, gesloten wereldbeeld, de snelheid waarmee (consumenten) verwachtingen vervuld kunnen worden en het verlangen van het hart dat gericht wordt op de 'tussentijd' van deze wereld in plaats van op God.

6 A.w., 124 wijst op de uitdaging van de seculiere context voor predikanten: 'Predikanten [...] hebben een scherp oog nodig voor de diverse factoren die het gebedsleven in onze tijd beïnvloeden'. 
door predikanten in de Protestantse Kerk in Nederland (PKN). Ik zoek daarin een antwoord op de vraag: wat draagt de praktijkervaring van deze predikanten bij aan een theologische visie op gebed en pastoraal bidden? De focus is daarbij gericht op de samenspraak. Eerst schets ik als theoretisch kader een driedimensionaal model van de samenspraak. $\mathrm{Na}$ een korte paragraaf over enkele methodische aspecten, beschrijf ik de resultaten van het onderzoek naar de praktijkervaringen van predikanten. In een volgende, normatieve paragraaf ga ik in op de theologische opvattingen over bidden van deze predikanten. Enkele conclusies en reflecties met betrekking tot pastoraal bidden als samenspraak besluiten deze bijdrage.

\section{Samenspraak}

Bidden versta ik hier als de houding van bereidheid en vertrouwen om contact met God te zoeken in een gebedshandeling van gesprek. Ik licht drie aspecten kort toe en laat zien hoe deze verbonden zijn met drie dimensies van het pastorale bidden als samenspraak. Het eerste aspect betreft de gebedshouding. Deze omvat het hele pastorale contact waarvan de gebedshandeling een onderdeel kan zijn. ${ }^{7}$ In de pastorale literatuur over bidden wordt aan dit aspect van de houding vaak voorbijgegaan doordat alleen wordt gesproken over de handeling van het samen bidden. ${ }^{8}$ De gebedshouding heeft twee kanten: een bereidheid aan de kant van de mens om het met God te wagen en een vertrouwen dat God 'op de een of andere wijze werkzaam is of wordt in de leefwereld van de biddende mens'. ${ }^{9}$ Deze houding van bereidheid en vertrouwen opent de dimensie van de voorbereiding op het gebed. Het betreft de ruimte waarin pastor en gesprekspartner(s) met elkaar afstemmen of en hoe zij wat besproken is zien in relatie tot het gebed. Het tweede aspect is de menselijke intentie van het zich richten tot God dat ik voorzichtig aanduid als

7 Voor het onderscheid tussen houding en handeling, zie: E. Thurneysen, Die Lehre von der Seelsorge, Zürich 1948, 165-173. Hij fundeert de gebedshandeling pneumatologisch in de houding van het geloof als door God geschonken ontvankelijkheid.

8 Zie b.v. PKN, Pastoraat en gebed. Handreiking voor het pastoraat, Utrecht 2009; KleinKranenburg, 'Samen in de naam van Jezus'.

9 G. Immink, Bidden in het besef van Gods tegenwoordigheid, Zoetermeer 2016, 16. Vgl. voor de houding als bereidheid en vertrouwen: B. Hoedemaker, Ik bid dus ik ben. Pleidooi voor de christelijke traditie, Middelburg 2018, 64-82, hier 77. Anders dan Hoedemaker zie ik de zin van bidden niet alleen in het zoeken van Gods aanwezigheid, maar ook in het verwachten dat God werkzaam is. Door die geloofsovertuiging heeft gebed een belijdend karakter. Zie Immink, Bidden, 16 en 114-117. 
contact zoeken. ${ }^{10}$ Met deze aanduiding wil ik rechtdoen aan de vragen over en de onbekendheid met God in de seculiere cultuur evenals aan de onbekendheid van God in de zin van het 'geheel anders zijn' van Gods onuitsprekelijke Naam. Mensen kunnen niet meer doen dan God zoeken, 'of zij Hem misschien al tastend zouden mogen vinden' (Hand. 17,27, HSV). Het vinden is afhankelijk van de Ander. Dit contact zoeken gebeurt in de gebedshandeling waarin pastor en gesprekspartner(s) samen bidden in een al of niet vertrouwde vorm. Het is de dimensie van het ritueel. ${ }^{11}$ Het derde aspect is het gesprek: een aanspreken van en luisteren naar God. Stilte 'hoort' daar ook bij. Het gesprek als dialoog veronderstelt een ontmoeting tussen de mens en God als twee subjecten. ${ }^{12}$ Anders gezegd: in het aanroepen van God is de menselijke geest betrokken op de externe werkelijkheid van de Ander. In die zin is bidden een wederkerige, maar asymmetrische betrekking tussen God en mens. ${ }^{13}$ Dit is de derde dimensie van de ontmoeting met God, 'in het besef van Gods tegenwoordigheid' (Immink).

Wat de vorm (en vaak ook wat de plaats, bij mensen thuis) betreft komt pastoraal bidden overeen met het samen bidden in het huisgezin. ${ }^{14}$ Deze gezamenlijke vorm staat in tussen het persoonlijke en het liturgische gebed. Het persoonlijke gebed is intiem: de bidder trekt zich terug om met God te verkeren in het verborgene van de privéruimte ('tameion', een afsluitbare binnen- of voorraadkamer, Matt. 6,6). Bidden gebeurt buiten het zicht en gehoor van anderen. Het liturgisch gebed daarentegen vindt plaats in de samenkomst van de gemeente, oorspronkelijk in de huisgemeente of de tempel (Handelingen 1,$14 ; 2,46 ; 4,24)$, later in de openbare ruimte van het kerkgebouw, waar kerkgangers samen Gods aangezicht zoeken.

Het pastorale bidden heeft iets van beide vormen. Als samenspraak gebeurt het enerzijds in de privésfeer, maar niet verborgen voor het oog en oor van de ander. Anderzijds gebeurt het samen, en is via de pastor de geloofsgemeenschap aanwezig, maar het is niet openbaar. Dit enigszins hybride

10 Vgl. PKN, Pastoraat en gebed, 6: bidden is niet alleen 'spreken met God', maar ook 'zoeken naar God', van Gods aangezicht.

11 Het (gebeds)ritueel wordt volgens C. Menken-Bekius, Werken met rituelen in het pastoraat, Kampen 2001, 36 gekenmerkt door symbolische handelingen vergezeld van bijbehorende formules en teksten en een bepaalde klank (script), 'waarin de mens lichamelijk en interactief betrokken is op een werkelijkheid die in het ritueel zelf present wordt gesteld'.

12 P.D. Dekker, 'Is het gebed een dialoog?', Theologia Reformata 61 (2018), 41-56.

13 Immink, Bidden, 23v.

14 P. Veerman, Themabrochure 21 'Samen bidden', 4 https://gereformeerdebond.nl/boekenbrochures/brochures-downloads/themabrochure-samen-bidden [bezocht 08-01-2020]. 
karakter roept bij de bovengenoemde drie aspecten vragen op: Is de houding van bereidheid en vertrouwen bij alle gesprekspartners aanwezig? Hoe krijgt de gebedshandeling concreet gestalte als je met twee of drie mensen bidt? Wie spreekt namens wie als contact met God gezocht wordt en wat wordt dan ter sprake gebracht? En delen de bidders de opvatting tot wie (of wat) zij spreken in het gesprek met God? Deze vragen nodigen uit tot samenspraak als voorbereiding op het gebed, maar wellicht ook in de vormgeving van het gebed als ritueel en in het aanroepen van God.

\section{Pastorale gevalsstudies}

Als onderzoeksmethode wordt hier gebruikgemaakt van gevalsstudies. In het kader van de permanente educatie konden predikanten in 2015 en 2017 tweedaagse postacademische cursussen volgen aan de Protestantse Theologische Universiteit (PThU) over bidden in het pastoraat. De deelnemers hadden de opdracht om vooraf een gevalsstudie te schrijven over pastoraal bidden in hun eigen praktijk en daarbij een leervraag te formuleren. Van de 37 deelnemers aan de twee cursussen schreven 31 een gevalsstudie, allen predikant in de PKN: van vrijzinnig tot Gereformeerde Bond, mannen en vrouwen, in leeftijd variërend tussen 37 en 63 jaar. De meeste gevalsstudies beschrijven een concrete casus en vier bevatten algemene reflecties op de eigen pastorale gebedspraktijk. Na de cursus hebben de predikanten deze gevalsstudie herschreven vanuit de bestudeerde pastorale theorie, de opgedane cursuservaringen en de leeropbrengst. De predikanten gaven schriftelijk toestemming voor het gebruik van hun gevalsstudie voor dit onderzoek en de publicatie daarvan. ${ }^{15}$ Citaten daaruit zijn tussen aanhalingstekens geplaatst.

In dit onderzoek is de focus niet gericht op de vraag wat en hoe predikanten daadwerkelijk pastoraal bidden, maar hoe zij zich verhouden tot de vragen die hun pastorale praktijk oproept. Aangezien zij dit doen in het kader van een cursus, is er sprake van een leerproces met vier fasen: 1 . beschrijving van gevalsstudie voorafgaand aan de cursus; 2 . individuele bestudering van de literatuur; 3. interactie tijdens colleges en bespreking van de casuïstiek in de cursus; en 4. reflectie achteraf op de gevalsstudie vanuit literatuur en besprekingen. In dit onderzoek richt ik me niet op dit leerproces, omdat informatie daarover van de deelnemers zelf grotendeels ontbreekt in de gevalsstudies en er overigens geen gebruik is gemaakt van dataverzameling via andere methodes.

Ik beperk me tot het onderzoeken van de gegevens in de gevalsstudies. Die betreffen twee fasen: 1 . de vragen die de predikanten vooraf beschrijven in de

15 Van de ene predikant die geen toestemming gaf, zijn geen citaten gebruikt. 
gevalsstudies en 2. de inzichten die zij als leeropbrengst in de reflectie achteraf benoemen als helpend om hun praktijk te verbeteren. Gezien de beperkte omvang en de inhoud van het materiaal (focus op de beleving en opvattingen van de deelnemers) is gekozen voor kwalitatief onderzoek waarbij ik de gevalsstudies onderzocht volgens de methode van de inhoudsanalyse. ${ }^{16}$ Daarbij zijn de 44 codes in de analyse geordend in 29 thema's (factoren die een rol spelen) die vervolgens via selectie geïntegreerd zijn in vier categorieen: pastor, gebedshandeling, begeleiding en gesprekspartner. De onderzoeksresultaten bespreek ik in twee stappen: eerst de vragen in de gevalsstudies, daarna de leeropbrengst. Het model van de driedimensionale samenspraak gebruik ik om de onderzoeksresultaten te duiden.

\section{Vragen rond pastoraal bidden}

Onder de leervragen van de predikanten in dit onderzoek is het meest voorkomende thema verlegenheid. Dat zou je bij beroepsbidders niet direct verwachten. Het beeld wordt wellicht scheefgetrokken doordat deze predikanten zich hebben opgegeven voor een cursus waarbij de focus gericht is op de vragen die zij in hun praktijk ervaren. De openhartigheid over de verlegenheid, zowel in de beschrijving voor als in de bespreking tijdens de cursus, maakt duidelijk dat er voor hen iets op het spel staat. Dat blijkt ook uit de termen die zij bezigen. Naast verlegenheid gebruiken ze soms meer cognitieve woorden als niet weten, dilemma, twijfel en aarzeling, maar veel vaker affectief geladen woorden als ongemak, spanning, schroom, onbevredigend, angst, machteloosheid, onzekerheid, onrust of zelfs worsteling. ${ }^{17}$

Predikanten ervaren die verlegenheid zeker niet allemaal en ook niet altijd. Ze komt op in specifieke situaties en bij bepaalde aanleidingen. De situatie kan betrekking hebben op de context van het gesprek, zoals een ziekenhuiskamer, of op de onbekende of aangrijpende situatie van de gesprekspartner, zoals diens leed waar de predikant geen raad mee weet. De predikant voelt zich op dat moment in dergelijke situaties unheimlich. Een voorbeeld is het bezoek van een predikant aan een echtpaar op de ic in het ziekenhuis. Hun tweeling is te vroeg geboren en de kans dat ze sterven is groot, evenals de kans dat ze blijven leven. De predikant beschrijft hoe hij de situatie ervaart:

16 H. Boeije, Analyseren in kwalitatief onderzoek. Denken en doen, Amsterdam 2008. Voor codering en analyse is de software van Atlas.ti gebruikt volgens de drie stappen van open, axiale en selectieve codering, zie: a.w., 84-110.

17 Klein-Kranenburg, 'Samen in de Naam van Jezus', 329v., noemt het gevoel van onmacht, twijfel en gebedsverlegenheid. 
Ik merk dat ik in mijn onderbuik onrustig word, alsof muizenpootjes aan mijn binnenste buikwand schrapen. Wat zal ik nu gaan zeggen in gebed?

Hij voelt de emoties van de ouders en ook de spanning bij zichzelf tussen het verlangen van de ouders en de eigen weerstand tegen bidden om genezing. Toch kan hij na een paar ademhalingen in alle rust bidden. En dat de ouders niet hebben gevraagd om bidden voor gezondheid, is voor hem een opluchting. Ze zijn blij met het gebed. Dit voorbeeld laat tegelijk zien dat predikanten in zulke situaties niet alleen maar ongemak ervaren: voor het echtpaar was het goed. Op positieve ervaringen van andere predikanten ga ik in bij de theologie vanwege het verband met de dimensie van de Godsontmoeting.

De aanleidingen hebben veelal te maken met verschillen tussen de gesprekspartners, met de inhoud van het gebed (wat moet ik bidden?), of met het automatisme van het afsluitingsritueel. De pastor ervaart dan twijfel (wel of niet te bidden?). Soms gaat het om factoren die met de pastor zelf te maken hebben. Genoemd worden de eigen houding en de biografie. Gebrek aan vrijmoedigheid of durf en een zekere geremdheid om het ongemak ter sprake te brengen kunnen verlegenheid oproepen. Daarbij kan ook de eigen biografie een rol spelen. Zo noemt een predikant ervaringen met samen bidden in koffiebars van Youth for Christ of bij christelijke jongerenevenementen die haar terughoudend hebben gemaakt in samen bidden. Ik ga nu nog wat meer in op de genoemde drie aanleidingen.

Het omgaan met verschillen roept bij veel predikanten vragen op. De verschillen kunnen tussen meerdere actoren een rol spelen: 1) tussen gesprekspartners onderling; 2) tussen de predikant en de gesprekspartner(s); en 3) tussen een gesprekspartner en de gemeente. Bij verschillen tussen de gesprekspartners vraagt de predikant zich af hoe hij/zij daaraan in het gebed recht kan doen. Een voorbeeld is de situatie van een jonge, ernstig zieke vader (niet kerkelijk meelevend) die strijdt om bij zijn gezin te blijven, terwijl zijn gezin (de vrouw is zeer betrokken kerklid) en de gemeente voorsorteren op het afscheid. 'Hoe blijf je in dit spanningsveld de zieke nabij?', zo vraagt de predikant. Predikanten ervaren bij het omgaan met zulke verschillen vooral cognitief enige twijfel.

Een grotere rol spelen de verschillen tussen de predikant en diens gesprekspartner(s). Een predikant die een zieke vrouw bezoekt, weet van haar dat zij 'het liefste zou willen dat ik bid om genezing'. Hij schrijft dan:

Maar dat kan ik niet en wil ik niet. Ik bid om kracht, om moed en om mensen om haar heen die haar blijven steunen; om Gods nabijheid bid ik, maar niet om genezing. Omdat ik daar op haar manier niet in kan geloven. Tegelijk blijft de vraag: zou ik dat niet toch moeten doen? 
Hij vraagt zich dus af hoe hij op een constructieve manier de verschillende godsbeelden van zichzelf en de gesprekspartner ter sprake kan brengen in het gebed. Het verschil in theologische visie op bidden om genezing uit zich in de dimensie van de gebedshandeling als ritueel: waar bid je om en met welke woorden? Bij zulke verschillen tussen predikanten en hun gesprekspartner(s) worden vooral affectief geladen termen gebruikt voor de verlegenheid met de situatie: spanning, aarzeling, lastig, frictie. Die emoties beïnvloeden de beleving van de Godsontmoeting.

De verschillen tussen gesprekspartners en de gemeente worden het minst genoemd, maar zijn voor de predikant lastig, omdat hij/zij de spanning kan ervaren tussen de verschillende belevingen, visies en loyaliteiten klem te zitten. Zo beschrijft een predikant in haar gevalsstudie de aanvankelijke verlegenheid die ze ervaart bij het verschil tussen een orthodoxe man die graag een gebed wil en zijn vrijzinnige, zieke vrouw voor wie dat niet hoeft. 'Ik wist niet goed wat ik er mee aan moest [...] Ik herinner me dat ik in het gebed behoorlijk gespannen was'. In haar reflectie achteraf noemt ze een tweede verschil, namelijk tussen haar als predikant en de vrouw: 'Hier [...] kwam ik ook in conflict met mijn eigen theologie'. Ze werkt vanuit de presentietheorie, maar ze heeft 'wel eens de behoefte om als voorganger van de gemeente ook dingen aan te reiken, mee te geven voordat er om gevraagd is'. Daarnaast is er nog een derde spanning tussen de gemeente, waar voorbede voor zieken in de kerkdienst op prijs wordt gesteld (wat de predikant ook waardeert en doet vanwege de gemeenschapszin) en de gesprekspartner die achteraf te kennen gaf dat ze daar geen prijs op stelde. Bij de predikant botsen hier twee rollen: voorganger van de gemeente en pastor van de zieke vrouw.

Een tweede aanleiding voor de verlegenheid betreft de inhoud: moet ik bidden en zo ja wat? De spanning rond de vraag 'moet ik wel of niet bidden?' komt voort uit waargenomen verschillen, vooral bij twee thema's: de verschillende verwachting rond bidden en het bidden om genezing. De verschillende verwachtingen roepen trouwens niet bij alle predikanten verlegenheid op. Sommigen passen zich in zulke situaties makkelijk aan aan de gesprekspartner en de situatie. Anderen ervaren wel ongemak bij deze de vraag, meestal omdat de predikant wel wil bidden, maar de gesprekspartner(s) niet, of omgekeerd. Een voorbeeld is de langer durende pastorale begeleiding van een vrouw die herstelt van kanker en die aan het eind van elk gesprek een gebed verwacht. De predikant krijgt echter steeds vaker het gevoel dat het voor haar een automatisme dreigt te worden. Ze schrijft: 'Ik kan natuurlijk zeggen dat ik liever geen gebed doe maar dat zou zeker bij deze vrouw niet goed vallen'.

Deze casus is tegelijk een voorbeeld van het andere verschilpunt: wel of niet bidden om genezing? Daarover kunnen zowel de pastoranten onderling als de 
predikant en de gesprekspartner van opvatting verschillen, bijvoorbeeld qua godsbeeld. De vraag is dan: Hoe omgaan met deze verschillen? En wat te bidden? Hoe de inhoud verwoorden? Bidden om genezing of om kracht, en wat versta je dan onder genezing? De theologische opvattingen daarover zijn divers, maar worden in de desbetreffende gevalsstudies zelden besproken. Een aantal predikanten noemt in dit verband de spanning tussen afstemmen op de ander en de eigen authenticiteit: hoe woorden vinden die passen bij de pastor zelf. 'Ik kan geen dingen doen of zeggen waar ik niet achter sta', schrijft een andere predikant. Wat bij deze vragen rond 'wel of niet bidden?' opvalt is dat predikanten nogal eens aangeven dat ze ontevreden zijn over hoe het gegaan is: wel gebeden, maar daar achteraf geen goed gevoel bij hebben, of niet gebeden, maar twijfelen of het niet anders had gemoeten. Omdat ze hun aarzeling niet bespreken (dimensie van de voorbereiding), werkt de ervaren spanning door tijdens de gebedshandeling (dimensie van het ritueel). Dat maakt begrijpelijk dat zij als leeropbrengst van de cursus allemaal het belang noemen om het gebed inhoudelijk met de gesprekspartner(s) te bespreken.

Voor sommige predikanten is de vraag naar de inhoud van het gebed (wat?) geworteld in de normatieve vraag aan welke ijkpunten het gebed moet voldoen (hoe?). Wanneer is het gebed verantwoord? Hoe doe ik het waardevol, zorgvuldig, moedig? Het betreft hier twee kanten: wordt God recht gedaan (dimensie van de Godsontmoeting) en wordt de gesprekspartner recht gedaan (dimensie van het ritueel)? Dus enerzijds de vraag: is het gebed geworteld in vertrouwen, is de verwachting van God theologisch verantwoord? Anderzijds de spanning tussen empathie en correctie in de manier van bidden. Zo vraagt een predikant zich af of zijn gebed niet te 'lievig' is: 'Maar is het wel moedig genoeg? Kun je niet ook te therapeutisch, te "bevestigend" bezig zijn? Zijn het echt van die tere zielen die ik moet ontzien of zijn het gewoon lange tenen die ik wil ontwijken? Mag het een onsje radicaler ...?' De reflectie van deze predikant laat zien hoe de vraag naar de inhoud (wat en hoe bidden?) verweven is met de eigen rolopvatting en de houding. Kortom: vragen rond de inhoud van het gebed bewegen zich in een veld met drie orientatiepunten: de aansluiting bij de gesprekspartner, de congruentie (authenticiteit) van de pastor en een theologisch verantwoord godsbeeld.

Een derde aanleiding voor de verlegenheid vormt het gebed als afsluitingsritueel. De beleving en evaluatie van deze traditionele vorm van het gebed wisselt, al overheerst de positieve waardering ervan. Toch geeft een aantal predikanten aan zich bewust te zijn van de mogelijke problemen van dit afsluitingsritueel. Met name worden genoemd het automatisme ervan, het niet goed aansluiten bij het gesprek ('geen organisch geheel') en het onvoldoende serieus nemen van de gesprekspartner als subject. In de dimensie van 
het ritueel is het dan de vraag of er werkelijk sámen gebeden wordt. Ook hier concluderen meerdere predikanten dat het goed is om het bidden zelf en de afsluiting van het gesprek met de gesprekspartner te bespreken.

\section{Leeropbrengst}

Tot nu toe zijn drie aanleidingen besproken voor de vragen bij het pastoraal bidden: verschillen, inhoud en afsluitingsritueel. Ook zijn enkele factoren genoemd die daarbij een rol spelen: de houding, biografie en theologische visie van de pastor, en de situatie, context, verwachting en godsbeelden bij de gesprekspartners. Naast deze thema's blijkt de gebedsverlegenheid in sterke mate verbonden te zijn met het thema rolopvatting aan de kant van de pastor. Predikanten ervaren daarbij onduidelijkheid in de eigen rolkeuze. In de leervraag zijn ze zich dat meestal niet zo bewust en formuleren ze het anders, namelijk als vraag hoe om te gaan met bijvoorbeeld een ongemakkelijke situatie of met bidden bij verschillen? Bij de reflectie op de leeropbrengst achteraf gaan veel predikanten wel nadrukkelijk in op hun rol. Daarnaast reflecteren zij op het bespreken van het gebed en de vormgeving ervan.

In de colleges tijdens de cursus zijn verschillende pastorale modellen besproken met de bijbehorende rollen van de pastor als getuige, helper, metgezel of tolk en gids. ${ }^{18}$ Ook het energetische model met de rol van de pastor als geestelijk leider en vertegenwoordiger van het heilige kreeg aandacht. ${ }^{19}$ In het pastoraal bidden kan de pastor op vergelijkbare wijze verschillende rollen vervullen: naast de voorbede voor de ander in de rol van de priester, kan de pastor ook als helper met de ander een geestelijke weg zoeken, als gids de ander helpen om zelf te bidden, of als leider de ander in contact brengen met de werking van het heilige. Meerdere predikanten noemen in dit verband ook hun ambtsopvatting: voorganger van de gemeente, vertegenwoordiger van de kerk of van God/Christus, dienaar.

Deze differentiatie in rollen hielp predikanten om hun anvankelijke verlegenheid duidelijker te benoemen. Een voorbeeld is de predikant die in zijn rolopvatting uitgaat van gelijkwaardigheid, maar merkt dat de ander daardoor overvraagd wordt. 'Voor haar hoeft bidden niet zo direct, maar ze wil mij dat "plezier" ook niet ontnemen', schrijft hij. Zo bezien gaat het dus om de dimensie van de gebedshandeling als ritueel. Echter, in de reflectie na de cursus merkt hij dat de kernvraag dieper ligt: 'Wat eigenlijk de vraag is: hoe

18 Ganzevoort, Zorg, 69v. Vgl. M. Josuttis, Die Einführung in das Leben, Gütersloh 1996, 12-17.

19 Josuttis, Einführung, 18-20. Verder uitgewerkt in dez., Segenskräfte. Potentiale einer energetischen Seelsorge, Gütersloh 2000. 
zie ik mijn rol? Wil ik een therapeutische pastor zijn die in die rol ook de spirituele vragen aan de orde wil stellen? Of wil ik ook [op] momenten "verkondigende pastor" zijn? En van daaruit komt de rol van gebed in een gesprek ook duidelijker uit de verf. Wat de predikant eerst zag als een verschil in verwachting, bepaalt hem bij nader inzien bij zijn eigen rolonduidelijkheid: wie wil ik voor de ander zijn? Die vraag betreft de houding en vraagt om samenspraak in de dimensie van de voorbereiding.

Naast verschil in verwachting merken predikanten in hun reflecties dat ze te weinig flexibel zijn in hun rolkeuze. Ze ervaren dat de gekozen rol soms niet goed past in de gegeven situatie. Ze worden zich door de cursus bewust dat bij het bidden professioneel gezien meerdere rollen aan de orde kunnen zijn: priester, voorganger, coach, gids, leraar, verkondiger, hulpverlener, begeleider, medemens. En dat geringe flexibiliteit de bron kan zijn van de ervaren spanning. Een predikant ervaart bijvoorbeeld schroom om met dertigers te bidden, omdat hij niet weet of zijn gebed wel aansluit bij hun geloofsuiting. Hij ziet zijn eigen rol als ambtelijk, als vertegenwoordiger van de kerk en als leraar en in het gebed heeft hij een liturgische rol, als voorganger van de gemeente. De twijfel over de aansluiting en de eigen schroom maken hem gespannen tijdens het gebed. Hij schrijft hierover (aansluitend bij Josuttis): 'Bij het gebed in deze casus was ik zelf te gespannen om die geestkracht te ervaren, denk ik. Het is dus belangrijk dat ik iets in het gesprek doe om die spanning te verkleinen of weg te nemen'. Door de cursus heeft hij geleerd dat naast de ambtelijke rol ook de polen van beroep (hulpverlener) en persoon (medemens) belangrijk zijn en dat voor randkerkelijken een hulpverlenende of persoonlijke invulling van de rol de voorkeur kan hebben. De predikant kan dan als coach de ander helpen zelf te bidden of als gids een voorbeeld geven hoe hij persoonlijk betrokken is in het gebed. Hij verbindt dat met een ander leerpunt: het belang om het bidden eerst te bespreken, zowel de gebedspraktijk van de ander, of het ontbreken daarvan, als alternatieve vormen en houdingen. Deze reflecties betreffen de samenspraak in de dimensie van de voorbereiding, maar het verminderen van de spanning kan volgens deze predikant helpen in de dimensie van de Godsontmoeting 'waar we iets van troost en geestkracht ervaren'.

Het bespreken van het pastoraal bidden is het tweede thema dat in de reflecties veel voorkomt, een thema uit de categorie begeleiding. Het gaat dan zowel om overleg over de vraag wel of niet bidden en zo ja, waarvoor, op welke manier en door wie, als om gesprek over het bidden zelf, bijvoorbeeld de betekenis ervan of de visie op verhoring. In de colleges tijdens de cursus zijn deze methodische aspecten behandeld. In de reflecties achteraf erkennen meerdere predikanten nadrukkelijk het belang van een gesprek over de 
genoemde aspecten. Zo schrijft een predikant: 'Ik realiseer me nu dat het van het grootste belang is om het gesprek aan te gaan'. We zagen al dat een enkeling ook de vormgeving van en de houding bij het bidden bespreekt. Het betreft hier de rol van gids of coach. In dat verband komt soms ook het bidden door de gesprekspartner ter sprake, iets waar Ganzevoort en Visser vanuit hun narratieve benadering sterk voor pleiten. ${ }^{20}$ Toch kiezen slechts enkele predikanten in hun reflectie voor deze positie; zij willen proberen de ander te activeren zelf te bidden.

Een derde thema dat als leeropbrengst van de cursus wordt genoemd is diversiteit in de vormgeving van het bidden. In de literatuur en de colleges is gewezen op het belang om rekening te houden met de verscheidenheid aan praktijken en behoeften bij hedendaagse gesprekspartners. Er is materiaal besproken waarin verschillende gebedsvormen (verbale, zoals psalm, liedtekst of gedicht, en non-verbale, zoals stilte of muziek), gebedsstijlen en lichaamshoudingen worden behandeld. ${ }^{21}$ Als leeropbrengst noemen de deelnemers de wens om de eigen handelingsmogelijkheden te verbreden: enerzijds het aanbieden en bespreken van andere vormen en houdingen (samenspraak in de dimensie van de voorbereiding) en anderzijds meer ruimte nemen en geven voor stilte en rust (samenspraak in de dimensie van het ritueel). Zo schrijft een predikant die iemand begeleidt met een traumatische ervaring: 'Ik zou nu met de vrouw bewuster op zoek willen naar gebedsvormen die voor haar wel veilig zijn'.

\section{Theologie van het pastoraal bidden}

Vrijwel alle predikanten denken in hun reflecties na over theologische aspecten van het pastoraal bidden. Daardoor geeft het materiaal inzicht in de rol die theologische normativiteit speelt in deze praktijk, namelijk de normativiteit van de predikanten zelf. ${ }^{22}$ Meerdere predikanten hebben behoefte aan

20 Ganzevoort, Zorg, 245 v. Zie mijn kritische bespreking in R.J. de Vries, 'Het pastorale gebed als afsluitingsritueel', Theologia Reformata 58/1 (2015), 20-22.

21 Ganzevoort, Zorg, 241v. Vgl. P. Ball, Introducing Spiritual Direction, Londen 2003, 82; J. Minderhoud (red.), Handboek voor gebed. Bezinning en handreiking voor de praktijk, Zoetermeer 2015, 195-203; PKN, Dienstboek, een proeve. Schrift, maaltijd, gebed, Zoetermeer 1998, 1145-1168.

22 Jos de Kock et al., 'Normativity in Empirical Youth Ministry Research', Journal of Youth and Theology 17 (2018), 81-103 onderscheiden vier lagen van normativiteit in praktischtheologisch onderzoek: van deelnemers in een religieuze praktijk, van de professionele praktijktheorie (zoals hier het geval is), van de academische theorie en van de metatheoretische fundering van het onderzoeksproject. 
verheldering van hun eigen theologische visie op bidden. Iemand schrijft: 'Tot op heden heb ik me nooit verdiept in de vraag naar de precieze rol van het gebed in het pastoraat en welke theologie ik daarbij hanteer. Het gebed in het pastoraat is in veel bezoeken een vanzelfsprekendheid'. Ook doen veel predikanten uitspraken over hun beleving van het pastoraal bidden. Die is meestal positief en theologisch geladen. Enkele citaten illustreren deze beleving: 'Heel persoonlijk, anders dan in een kerkdienst', 'een intense driezijdige ontmoeting', 'als ik bid ervaar ik ook kracht [...] iets dat groter is dan mijzelf, 'dat we samen een moment van intimiteit hebben', 'dat de ruimte om ons heen gevuld is met warmte en aanwezigheid', 'gebed voelt als levendige getuige zijn van Gods werk in de wereld', 'het is teer en overstijgt mij'. De rode draad is de visie op gebed als verbinding of ontmoeting met God. In de reflecties wordt dit besef van Gods tegenwoordigheid verbonden met de relatie tussen pastor en gesprekspartner.

Die positieve beleving sluit overigens het gevoel van verlegenheid niet uit, maar is er de keerzijde van. De onderzoeksresultaten laten zien dat de verlegenheid wordt opgeroepen bij bepaalde situaties en aanleidingen en samenhangt met bepaalde factoren. Dan ervaren predikanten het pastoraal bidden niet als 'een echt gebed'. Een voorbeeld: 'Ik bid wel. Maar dat bidden voelt op dat moment niet goed'. Een echt gebed beantwoordt aan de positieve beleving en de verlegenheid functioneert als een signaal van een belemmerende factor. Aan de hand van vier aspecten werk ik nu kort uit hoe de predikanten het pastoraal bidden theologisch verstaan en ik verbind dit met de drie dimensies van de samenspraak.

Het eerste aspect betreft de aard van het pastorale gebed als een relationeel gebeuren waarin pastor, gesprekspartner en God betrokken zijn. Sommigen spreken van een 'driehoek' of omschrijven dit: 'Bidden schept relatie tussen de bidder en God. En tussen bidders onderling'. Andere typeringen van deze ontmoeting met God zijn: het is 'heilige communicatie', 'deel hebben aan het heilige in relatie tot de Heilige', het is een intensivering van de relatie, als het samen betreden van 'een andere ruimte', 'dat de inhoud van het gesprek op een ander niveau geheven wordt door het voor God te brengen'. Iemand noemt het gebed als 'de ultieme plek om in dergelijke zware omstandigheden te zoeken naar troost en hulp, en om niet te eindigen in sprakeloosheid. Het voelt als een laatste houvast'. Kortom: de relatie tussen pastor en gesprekspartner die tijdens het gesprek vorm krijgt (dimensie van de voorbereiding) wordt tijdens de gebedshandeling (dimensie van het ritueel) verbonden met en geïntensiveerd door het besef van Gods aanwezigheid (dimensie van de Godsontmoeting). Deze drie dimensies van de samenspraak zijn met elkaar verweven. 
Als tweede aspect noemen predikanten hun eigen rol in deze 'driezijdige ontmoeting', met name hun houding en ambt. Voor de ontmoeting met God zijn het eigen gebedsleven en de openheid zowel naar God als naar de gesprekspartner(s) van belang (dimensie van de voorbereiding), zoals iemand schrijft: 'Het zelf biddend in het pastoraat staan, door van tevoren en tijdens het gesprek zelf open te staan voor Gods leiding in het gesprek. En door na het gesprek het geheel in Gods handen te leggen'. De betekenis van het ambt is gelegen in de verwijzende functie tijdens het bidden (dimensie van het ritueel). Dat gebeurt op twee manieren. Enerzijds vertegenwoordigt de predikant de gemeenschap van Christus, lokaal en wereldwijd. Op die manier wordt in het gebed 'ook de pastorant deel van de gemeenschap'. Anderzijds verwijst de ambtelijke aanwezigheid 'naar Hem wiens Naam de belofte van zijn aanwezigheid is'. Voor veel predikanten staat dit godsbeeld centraal in het pastoraal bidden: Gods immanentie, zijn aanwezigheid en nabijheid die werkt als bron van kracht en troost. 'Een immanent Godsbeeld helpt. God is er al met zijn werk nog voordat pastor en pastorant iets bij elkaar te weeg brengen'. In die verwijzende functie krijgt het bidden volgens Immink een belijdend karakter. ${ }^{23}$ Overigens wijzen sommige predikanten ook op Gods transcendentie, zijn heiligheid en vrijheid: 'We kunnen vol hoop bidden, maar niet afdwingen'. Dit besef kan ook ruimte geven eventueel niet te bidden: 'Het hangt niet van mij af.

Een derde aspect is de impact die de taal van de predikant in het gebed heeft op de gesprekspartner (dimensie van het ritueel). Enkele predikanten staan stil bij de mogelijkheid dat het eigen godsbeeld en daarmee de aanspraak van God een belemmering kan vormen voor de ander om God te ontmoeten. Een predikant die een echtpaar begeleidt en in het gebed wat geloofsvoorstellingen en taal betreft aansluit bij de man, merkt achteraf op: 'De formele en Bijbelse aanpak kan in deze situatie te veel gericht zijn op de man; de vrouw zou zich buitengesloten hebben kunnen gevoeld'. Een andere predikant ziet God als inspiratiebron die helpt en kracht geeft, maar ze merkt dat sommige gemeenteleden het lastig vinden om dat mee te maken. Sinds een tijd gebruikt ze daarom meerdere aanspreektitels voor God. ${ }^{24}$

Het vierde aspect is de werking van het gebed. Dat betreft de vraag hoe de gebedshandeling verbonden is met het besef van Gods aanwezigheid. In de reflecties verhouden de predikanten zich tot de literatuur en kiezen ze theolo-

23 Immink, Bidden, 114.

24 Ganzevoort, Zorg, 247-251 typeren de genoemde voorbeelden respectievelijk als roldiscrepantie (de godsbeelden sluiten niet aan) en rolrigiditeit (versmalling van het repertoire aan rollen in het godsbeeld). 
gisch voor verschillende benaderingen. Een eerste interpretatie ziet het gebed als performatieve handeling. Volgens Ganzevoort en Visser brengt bidden 'werkelijkheden tot stand die er daarvoor niet waren of houdt die werkelijkheden in stand'. ${ }^{25}$ Immink spreekt van een evocerende kracht: 'De biddende mens komt in een betrekking tot God en wordt zich bewust van de presentie en de werking van God'. ${ }^{26}$ Kortom, zoals een predikant schrijft: 'Samen bidden doet iets met je'. Een tweede interpretatie ziet de werking van het bidden niet alleen in de subjectieve ervaring van de mens, maar ook in het handelen van God die ons als Ander tegemoetkomt. ${ }^{27}$ Zo vraagt een predikant: 'Is het gebed [...] niet dus ook méér dan performaal (denk aan het bidden van de Geest; de Geest die bidt waar wij niet weten wat wij bidden zullen [...]?' Anderen noemen de leiding van God, wonderen die God doet, of de zegen van God 'die direct neerdaalt op de ander' [...] 'zonder tussenkomst van de pastor'. Een derde interpretatie sluit aan bij het energetische model van Josuttis: het gebed als bemiddeling van levenskracht. Het is niet duidelijk of deze predikanten ook diens visie delen op de rol van de pastor als geestelijk leider.

In deze fragmentarische theologie van het pastorale bidden worden drie functies genoemd: relationele verbinding (driehoek), inhoudelijke verwijzing naar God en de performatieve of evocatieve werking. Ook worden meer of minder expliciet de drie dimensies van de samenspraak met elkaar verweven: de open houding om het gebed te bespreken, het samen bidden tijdens de gebedshandeling en de Godsontmoeting. Die verbinding voelt voor deze predikanten als 'echt bidden'. Dat betekent omgekeerd dat de predikant de Godsontmoeting niet ervaart als echt gebed wanneer dit geen organisch geheel vormt met het gesprek of als het gebedsritueel een automatisme is (dimensie van het ritueel). Hetzelfde geldt voor de dimensie van de voorbereiding, als de verschillen in verwachting en godsbeelden niet gedeeld worden, als in de relatie met de ander een bepaald grondgevoel ontbreekt of als de predikant zich te gespannen voelt. Hierover samen spreken is meer dan een communicatieve voorwaarde, het is een 'intiem moment' waarin een geestelijke band wordt gevormd. ${ }^{28}$

Een fundering voor deze fragmentarische theologie biedt Bonhoeffers Gemeenschapsleven. ${ }^{29}$ Daarin beschouwt hij de christelijke gemeenschap als

25 A.w., 253.

26 Immink, Bidden, 113.

27 Vgl. hiervoor: a.w., 114-115 en 23-25.

28 PKN, Pastoraat en gebed, 8.

29 D. Bonhoeffer, Gemeenschapsleven, in: dez., Verborgen omgang, Baarn 2003, 13-35. 
geestelijke ('pneumatische') werkelijkheid die hij onderscheidt van de psychische werkelijkheid. De eerste is geworteld in Jezus Christus en komt tot stand door de Heilige Geest, de tweede is natuurlijk van aard en komt voort uit de aanleg van de menselijke ziel. Voor de pastorale ontmoeting betekent dit dat een christen alleen tot de ander komt door Jezus Christus. En in die gemeenschap met de ene broeder of zuster is mij de gemeenschap met de gehele gemeente al gegeven'. ${ }^{30}$ De geestelijke gemeenschap ontstaat dus niet pas wanneer samen wordt gebeden, maar is al een door God in Christus geschapen werkelijkheid in de gespreksrelatie tussen pastor en gesprekspartner. Anders gezegd: in het pastoraat heeft deze geestelijke gemeenschap het karakter van een driedimensionale samenspraak.

\section{Samenspraak: conclusies en reflecties}

Deze bijdrage zocht een antwoord op de vraag wat de praktijkervaring van PKN-predikanten met pastoraal bidden bijdraagt aan een theologische visie op gebed als samenspraak? De conclusies hebben een beperkte reikwijdte. Het materiaal is immers beperkt qua omvang en inhoud. Het is ook eenzijdig, omdat het alleen de ervaring van predikanten betreft (en niet van de gesprekspartners). En het materiaal is indirect, omdat de kennis van die ervaring gebaseerd is op de waarneming, beschrijving en reflectie van de predikanten zelf. Een beperking is verder dat de analyse en interpretatie van het materiaal door de onderzoeker niet gedeeld zijn met een onderzoeksgroep of met de deelnemers aan de cursus. De conclusies zijn daarom vooral bedoeld om te reflecteren op de theologische kwaliteit van het samen spreken over het gebed in het pastoraat.

Blijkens de praktijkervaring van de deelnemende predikanten spelen verlegenheid, verschillen, rolonduidelijkheid en rolfixatie van de pastor een belemmerende rol bij pastoraal bidden. Vragen rond hoe om te gaan met verschillende verwachtingen, (theologische) opvattingen en godsbeelden roepen spanning op. Het onderzoek laat zien dat predikanten de genoemde vragen zelden met de gesprekspartner(s) bespreken, maar door deelname aan de cursus het belang daarvan duidelijker onderkennen en erkennen. In deze bijdrage pleit ik er daarom voor dat pastores als voorbereiding van het pastoraal bidden inhoud, vormgeving en rolverdeling daarvan afstemmen met de gesprekspartner(s). Ook de gebedspraktijk van de ander kan daarbij besproken worden. Ik zie daarvoor twee redenen: de theologische kwaliteit en het praktische belang van de samenspraak. 
Om de theologische kwaliteit te verhelderen geef ik een aanzet voor een theologie van het pastoraal bidden. Het onderzoek reikt voor deze theologie drie bouwstenen aan. Allereerst laten de gevalsstudies zien dat de drie aspecten van de samenspraak (houding, gebedshandeling en gesprek met God) door de predikanten zelf vaak met elkaar verbonden worden. Ze spreken dan van een 'echt gebed'. In de tweede plaats reikt het driedimensionale model van de samenspraak (als voorbereiding, ritueel en Godsontmoeting) een theoretisch concept aan om de verwevenheid van de drie aspecten op fragmentarische wijze theologisch te verstaan. In de derde plaats helpt Bonhoeffers visie op de pastorale ontmoeting als geestelijke gemeenschap om de samenspraak theologisch te onderbouwen.

In aansluiting bij Immink, Hoedemaker en Ganzevoort en Visser heb ik erop gewezen hoe in het praktijkmateriaal de verwijzende en de performatieve functie (geloofsinhoud en werking) ook voor het pastoraal bidden kenmerkend zijn. Hier worden beide functies echter gecompliceerd doordat er zich tussen de gesprekspartners (pastor en anderen) verschillen kunnen voordoen zowel in theologische opvattingen over het geloof in God als in de verwachting of de geestesgesteldheid ten aanzien van de werking van het gebed. Dat kan een bron van spanning zijn. Het is dan van belang om de mogelijke verschillen te verkennen en verhelderen. Het eerdergenoemde hybride karakter van het pastoraal bidden vraagt om duidelijkheid wat betreft geloof, houding en intentie bij de bidders: wie of wat zoeken zij? Anders gezegd: de samenspraak met God tijdens de gebedshandeling vraagt om samenspraak tussen de pastor en de gesprekspartner voorafgaand aan het gebed. In aanvulling op wat er in de literatuur over bidden gezegd wordt over beide genoemde functies laat dit onderzoek zien dat voor pastoraal bidden als derde de verbindende functie kenmerkend is. Dat hangt samen met de vertrouwelijkheid van de pastorale relatie en de intimiteit van het samen bidden in kleine kring. Het delen in de Godsontmoeting intensiveert de ontmoeting tussen de gesprekspartners.

De theologische kwaliteit van de samenspraak heeft op drie manieren praktische waarde. 1) Het kan predikanten helpen zich beter bewust te zijn van hun verlegenheid, niet als belemmering maar als een signaal, en te onderzoeken wat dit betekent. Zij kunnen er in de voorbereiding of het gebed dan iets mee doen in plaats van er innerlijk door verward of verlamd te raken. Dat kan hun gevoel van vrijheid en autonomie vergroten, waardoor zij in de samenspraak hun eigen rol duidelijker kunnen innemen en waar nodig differentiëren. 2) Voor de gesprekspartners kan de samenspraak de wederkerigheid bevorderen waardoor zij zich meer als subject erkend voelen en op een voor hen passende manier deel kunnen nemen in het gebed. Dat kan bij hen een houding van bereidheid en vertrouwen bevorderen en zo de betrokken- 
heid in het gebed vergroten. 3) De gebedshandeling kan door de samenspraak duidelijker en meer gevarieerd ingevuld worden, zowel wat betreft de inhoud (wat zullen we bidden?), als wat betreft de vorm (hoe zullen we bidden?), als wat betreft de rolverdeling (wie doet wat?). Die duidelijkheid kan bijdragen aan onderlinge verbondenheid, geestelijke ruimte en openheid naar de Levende, die wij 'misschien al tastend mogen vinden'.

R.J. de Vries was universitair docent praktische theologie/pastoraat aan de PThU, locatie Amsterdam. 